\title{
Biochemical Analysis of Initiator Caspase-Activating Complexes: The Apoptosome and the Death-Inducing Signaling Complex
}

\author{
Claudia Langlais, Michelle A. Hughes, Kelvin Cain, ${ }^{1}$ and Marion MacFarlane ${ }^{1}$ \\ MRC Toxicology Unit, Hodgkin Building, Leicester LE1 9HN, United Kingdom
}

\begin{abstract}
Apoptosis is a highly regulated process that can be initiated by activation of death receptors or perturbation of mitochondria causing the release of apoptogenic proteins. This results in the activation of caspases, which are responsible for many of the biochemical and morphological changes associated with apoptosis. Caspases are normally inactive and require activation in a cascade emanating from an "initiator" or activating caspase, which in turn activates a downstream or "effector" caspase. Activation of initiator caspases is tightly regulated and requires the assembly of caspase- 9 (via mitochondrial perturbation) or caspase- $8 / 10$ (via death receptor ligation) activating complexes, which are termed the apoptosome and the death-inducing signaling complex (DISC), respectively. These large multiprotein complexes can initially be separated according to size by gel filtration chromatography and subsequently analyzed by affinity purification or immunoprecipitation. The advantage of combining these techniques is one can first assess the assembly of individual components into a multiprotein complex, and then assess the size and composition of the native functional signaling platform within a particular cell type alongside a biochemical analysis of the enriched/purified complex. Here, we describe various methods currently used for characterization of the apoptosome and DISC.
\end{abstract}

Many key biological processes, including apoptosis, are initiated from or performed in large multiprotein complexes. Apoptosis signaling complexes that can initiate cell death include the apoptosome and the death-inducing signaling complex (DISC) (Bratton et al. 2000; Cain et al. 2002; MacFarlane 2003; Dickens et al. 2012b). Typically, apoptosis is triggered through activation of either the intrinsic (mitochondrial) or extrinsic (death receptor) pathway. Central for activation of the intrinsic pathway is the cytosolic Apaf-1/Caspase-9 apoptosome, a $>700-1000-\mathrm{kDa}$ complex formed following release of cytochrome $c$ from mitochondria (Cain et al. 2002). In contrast, the extrinsic pathway is triggered by formation of the DISC at the plasma membrane; in this case, ligation of the death receptors CD95, TRAIL-R1, or TRAIL-R2 by their cognate ligands results in recruitment of the adaptor molecule FADD, the initiator caspase procaspase-8, and additional modulator proteins such as cFLIP (Dickens et al. 2012b).

It is now increasingly evident that the composition and stoichiometry of components within key cell death signaling platforms can determine not only the final signaling outcome but also the mode of cell death. By analyzing these complexes, we can learn how cell death is regulated as well as how key cell death signaling

\footnotetext{
${ }^{1}$ Correspondence: mm21@leicester.ac.uk; kc5@le.ac.uk

(c) 2015 Cold Spring Harbor Laboratory Press

Cite this introduction as Cold Spring Harb Protoc; doi:10.1101/pdb.top070326
} 
platforms like the apoptosome and DISC might be targeted for therapeutic benefit (MacFarlane 2009; Cain 2010). The successful application of a range of methodologies which couple characterization of complex assembly together with subsequent purification and biochemical analysis can therefore provide novel insights into how cell death signaling platforms are regulated in both normal cell physiology and disease.

Large multiprotein complexes such as the apoptosome and DISC can be separated according to their size by gel filtration chromatography and further purified by subsequent affinity purification or immunoprecipitation. By combining these methods, an indication of the size of the complex as well as the recruitment of individual components associated with the active complex can be determined, thus providing more precise and selective information on the complex itself. This combined approach has been used to purify and characterize the active apoptosome complex (Cain et al. 1999, 2000; Twiddy et al. 2006) and, more recently, we and others have used gel filtration to identify and characterize the ripoptosome (Feoktistova et al. 2011; Tenev et al. 2011). Intriguingly, this complex, depending on its protein composition, can switch between apoptotic and necrotic modes of cell death. Similarly, the complementary approach of sucrose density gradient centrifugation has been combined with immunoprecipitation/affinity purification to characterize both the active apoptosome complex, and, more recently, the native TRAIL DISC using mass spectrometry (Twiddy et al. 2004; Dickens et al. 2012a; Hughes et al. 2013). Indeed, affinity purification of the DISC using biotin-labeled ligands not only provided novel insights into the mechanisms that regulate death receptor signaling in diverse cell types and upon different treatment regimens (Harper et al. 2001, 2003a, 2003b; MacFarlane et al. 2002, 2005; Harper and MacFarlane 2008; Robinson et al. 2012), but also led us to propose a death effector domain (DED) chain DISC model and a crucial role for caspase-8 chain assembly in mediating apoptotic cell death (Dickens et al. 2012a).

\section{ANALYZING THE APOPTOSOME AND DISC}

In the accompanying protocols, we describe the various techniques and strategies we have developed over several years to successfully isolate and characterize two key initiator caspase-activating complexes, namely the apoptosome and DISC. The dATP-activation of caspases in cellular lysates has been used for many years as an in vitro model system for assembling the apoptosome complex and studying its characteristics, components, and activity (Cain et al. 1999, 2000, 2001; Beere et al. 2000; Freathy et al. 2000; Almond et al. 2001; Bratton et al. 2001; Thompson et al. 2001; Lademann et al. 2003; Twiddy et al. 2004, 2006; Hughes et al. 2013). The basis of the model, detailed in Protocol: In Vitro Assembly and Analysis of the Apoptosome Complex (Langlais et al. 2015), is production of a cell-free extract from a cell line of choice (e.g., the human monocytic tumor cell line THP.1) in which caspases can be processed and activated in vitro by treatment with $\mathrm{dATP} / \mathrm{MgCl}_{2}$ and cytochrome $c$ (Liu et al. 1996; Li et al. 1997). As an alternative to apoptosome assembly based on cell lysates, a full in vitro reconstitution of the apoptosome is also feasible (Cain et al. 2001; Zou et al. 2003). In both cases, apoptosome assembly and caspase-dependent cleavage are analyzed using gel filtration in conjunction with western blotting and fluorimetric assays for effector caspase activity.

Our Protocol: Activation, Isolation, and Analysis of the Death-Inducing Signaling Complex (Hughes et al. 2015) is based on affinity purification using biotin-labeled antibodies and streptavidin beads for activation and capture of the native DISC complex. Triggering of receptor aggregation by the agonistic anti-CD95 antibodies (or the cognate CD95 ligand) leads to recruitment of the bipartite adaptor molecule FADD, which in turn binds the initiator caspase, procaspase-8, through its aminoterminal DED motifs (Peter and Krammer 2003; Dickens et al. 2012a; Schleich et al. 2012). On binding to FADD, procaspase- 8 is activated through proximity-induced dimerization of adjacent procaspase- 8 molecules, leading to proteolytic cleavage and maximal caspase-8 activation (Muzio et al. 1998; Boatright et al. 2003; Hughes et al. 2009). Activation of caspase-8 at the native DISC leads to cleavage and activation of downstream substrates, such as procaspase- 3 and BID, amplification of the caspase cascade and subsequent apoptosis. Composition of the isolated DISC and caspase activation can be analyzed via western blot and fluorimetric assays for caspase-dependent cleavage. 


\section{REFERENCES}

Almond JB, Snowden RT, Hunter A, Dinsdale D, Cain K, Cohen GM. 2001. Proteasome inhibitor-induced apoptosis of B-chronic lymphocytic leukaemia cells involves cytochrome c release and caspase activation, accompanied by formation of an approximately $700 \mathrm{kDa}$ Apaf- 1 containing apoptosome complex. Leukemia 15: 1388-1397.

Beere HM, Wolf BB, Cain K, Mosser DD, Mahboubi A, Kuwana T, Tailor P, Morimoto RI, Cohen GM, Green DR. 2000. Heat-shock protein 70 inhibits apoptosis by preventing recruitment of procaspase- 9 to the Apaf-1 apoptosome. Nat Cell Biol 2: 469-475.

Boatright KM, Renatus M, Scott FL, Sperandio S, Shin H, Pedersen IM, Ricci JE, Edris WA, Sutherlin DP, Green DR, et al. 2003. A unified model for apical caspase activation. Mol Cell 11: 529-541.

Bratton SB, MacFarlane M, Cain K, Cohen GM. 2000. Protein complexes activate distinct caspase cascades in death receptor and stress-induced apoptosis. Exp Cell Res 256: 27-33.

Bratton SB, Walker G, Roberts DL, Cain K, Cohen GM. 2001. Caspase-3 cleaves Apaf- 1 into an approximately $30 \mathrm{kDa}$ fragment that associates with an inappropriately oligomerized and biologically inactive approximately 1.4 MDa apoptosome complex. Cell Death Differ 8: $425-433$.

Cain K. 2010. Chemical regulation of the apoptosome: New alternative treatments for cancer. In Apoptosome: An up-and-coming therapeutical tool (ed. F Cecconi, M D’Amelio), pp. 41-74. Springer, Dordrecht, The Netherlands.

Cain K, Brown DG, Langlais C, Cohen GM. 1999. Caspase activation involves the formation of the aposome, a large (approximately $700 \mathrm{kDa}$ ) caspase-activating complex. J Biol Chem 274: 22686-22692.

Cain K, Bratton SB, Langlais C, Walker G, Brown DG, Sun XM, Cohen GM. 2000. Apaf-1 oligomerizes into biologically active approximately 700 $\mathrm{kDa}$ and inactive approximately $1.4-\mathrm{MDa}$ apoptosome complexes. J Biol Chem 275: 6067-6070.

Cain K, Langlais C, Sun XM, Brown DG, Cohen GM. 2001. Physiological concentrations of $\mathrm{K}^{+}$inhibit cytochrome $c$-dependent formation of the apoptosome. J Biol Chem 276: 41985-41990.

Cain K, Bratton SB, Cohen GM. 2002. The Apaf-1 apoptosome: A large caspase-activating complex. Biochimie 84: 203-214.

Dickens LS, Boyd RS, Jukes-Jones R, Hughes MA, Robinson GL, Fairall L, Schwabe JW, Cain K, MacFarlane M. 2012a. A death effector domain chain DISC model reveals a crucial role for caspase- 8 chain assembly in mediating apoptotic cell death. Mol Cell 47: 291-305.

Dickens LS, Powley IR, Hughes MA, MacFarlane M. 2012b. The 'complexities' of life and death: Death receptor signalling platforms. Exp Cell Res 318: 1269-1277.

Feoktistova M, Geserick P, Kellert B, Dimitrova DP, Langlais C, Hupe M, Cain K, MacFarlane M, Hacker G, Leverkus M. 2011. cIAPs block Ripoptosome formation, a RIP1/caspase-8 containing intracellular cell death complex differentially regulated by cFLIP isoforms. Mol Cell 43: 449-463.

Freathy C, Brown DG, Roberts RA, Cain K. 2000. Transforming growth factor- $\beta_{1}$ induces apoptosis in rat $\mathrm{FaO}$ hepatoma cells via cytochrome $\mathrm{c}$ release and oligomerization of Apaf-1 to form a approximately 700-kd apoptosome caspase-processing complex. Hepatology 32: 750-760.

Harper N, MacFarlane M. 2008. Recombinant TRAIL and TRAIL receptor analysis. Methods Enzymol 446: 293-313.

Harper N, Farrow SN, Kaptein A, Cohen GM, MacFarlane M. 2001. Modulation of tumor necrosis factor apoptosis-inducing ligand-induced NF- $\mathrm{KB}$ activation by inhibition of apical caspases. J Biol Chem 276: 34743-34752.

Harper N, Hughes M, MacFarlane M, Cohen GM. 2003a. Fas-associated death domain protein and caspase- 8 are not recruited to the tumor necrosis factor receptor 1 signaling complex during tumor necrosis factor-induced apoptosis. J Biol Chem 278: 25534-25541.

Harper N, Hughes MA, Farrow SN, Cohen GM, MacFarlane M. 2003b. Protein kinase $\mathrm{C}$ modulates tumor necrosis factor-related apoptosisinducing ligand-induced apoptosis by targeting the apical events of death receptor signaling. J Biol Chem 278: 44338-44347.
Hughes MA, Harper N, Butterworth M, Cain K, Cohen GM, MacFarlane M. 2009. Reconstitution of the death-inducing signaling complex reveals a substrate switch that determines CD95-mediated death or survival. Mol Cell 35: 265-279.

Hughes MA, Langlais C, Cain K, MacFarlane M. 2013. Isolation, characterisation and reconstitution of cell death signalling complexes. Methods 61: 98-104.

Hughes MA, Langlais C, Cain K, MacFarlane M. 2015. Activation, isolation, and analysis of the death-inducing signaling complex. Cold Spring Harb Protoc doi: 10.1101/pdb.prot087098.

Lademann U, Cain K, Gyrd-Hansen M, Brown D, Peters D, Jaattela M. 2003. Diarylurea compounds inhibit caspase activation by preventing the formation of the active 700-kilodalton apoptosome complex. Mol Cell Biol 23: 7829-7837.

Langlais C, Hughes MA, Cain K, MacFarlane M. 2015. In vitro assembly and analysis of the apoptosome complex. Cold Spring Harb Protoc doi: $10.1101 /$ pdb.prot087080.

Li P, Nijhawan D, Budihardjo I, Srinivasula SM, Ahmad M, Alnemri ES, Wang X. 1997. Cytochrome $\mathrm{c}$ and dATP-dependent formation of Apaf1/caspase-9 complex initiates an apoptotic protease cascade. Cell 91: 479-489.

Liu X, Kim CN, Yang J, Jemmerson R, Wang X. 1996. Induction of apoptotic program in cell-free extracts: Requirement for dATP and cytochrome c. Cell 86: 147-157.

MacFarlane M. 2003. TRAIL-induced signalling and apoptosis. Toxicol Lett 139: 89-97.

MacFarlane M. 2009. Cell death pathways-potential therapeutic targets. Xenobiotica 39: 616-624.

MacFarlane M, Harper N, Snowden RT, Dyer MJ, Barnett GA, Pringle JH, Cohen GM. 2002. Mechanisms of resistance to TRAIL-induced apoptosis in primary B cell chronic lymphocytic leukaemia. Oncogene 21:6809-6818.

MacFarlane M, Kohlhaas SL, Sutcliffe MJ, Dyer MJ, Cohen GM. 2005. TRAIL receptor-selective mutants signal to apoptosis via TRAIL-R1 in primary lymphoid malignancies. Cancer research 65: 11265-11270.

Muzio M, Stockwell BR, Stennicke HR, Salvesen GS, Dixit VM. 1998. An induced proximity model for caspase-8 activation. J Biol Chem 273: 2926-2930.

Peter ME, Krammer PH. 2003. The CD95(APO-1/Fas) DISC and beyond. Cell Death Differ 10: 26-35.

Robinson GL, Dinsdale D, MacFarlane M, Cain K. 2012. Switching from aerobic glycolysis to oxidative phosphorylation modulates the sensitivity of mantle cell lymphoma cells to TRAIL. Oncogene 31: 4996-5006.

Schleich K, Warnken U, Fricker N, Ozturk S, Richter P, Kammerer K, Schnolzer M, Krammer PH, Lavrik IN. 2012. Stoichiometry of the CD95 death-inducing signaling complex: Experimental and modeling evidence for a death effector domain chain model. Mol Cell 47: 306-319.

Tenev T, Bianchi K, Darding M, Broemer M, Langlais C, Wallberg F, Zachariou A, Lopez J, MacFarlane M, Cain K, et al. 2011. The Ripoptosome, a signaling platform that assembles in response to genotoxic stress and loss of IAPs. Mol Cell 43: 432-448.

Thompson GJ, Langlais C, Cain K, Conley EC, Cohen GM. 2001. Elevated extracellular $\left[\mathrm{K}^{+}\right]$inhibits death-receptor- and chemical-mediated apoptosis prior to caspase activation and cytochrome $c$ release. Biochem J 357: 137-145.

Twiddy D, Brown DG, Adrain C, Jukes R, Martin SJ, Cohen GM, MacFarlane M, Cain K. 2004. Pro-apoptotic proteins released from the mitochondria regulate the protein composition and caspase-processing activity of the native Apaf-1/caspase-9 apoptosome complex. J Biol Chem 279: 19665-19682.

Twiddy D, Cohen GM, MacFarlane M, Cain K. 2006. Caspase-7 is directly activated by the approximately $700-\mathrm{kDa}$ apoptosome complex and is released as a stable XIAP-caspase-7 approximately $200-\mathrm{kDa}$ complex. J Biol Chem 281: 3876-3888.

Zou H, Yang R, Hao J, Wang J, Sun C, Fesik SW, Wu JC, Tomaselli KJ, Armstrong RC. 2003. Regulation of the Apaf-1/Caspase-9 apoptosome by caspase-3 and XIAP. J Biol Chem 278: 8091-8098. 


\section{Biochemical Analysis of Initiator Caspase-Activating Complexes: The Apoptosome and the Death-Inducing Signaling Complex}

Claudia Langlais, Michelle A. Hughes, Kelvin Cain and Marion MacFarlane

Cold Spring Harb Protoc; doi: 10.1101/pdb.top070326

\begin{tabular}{|c|c|}
\hline $\begin{array}{r}\text { Email Alerting } \\
\text { Service }\end{array}$ & Receive free email alerts when new articles cite this article - click here. \\
\hline $\begin{array}{l}\text { Subject } \\
\text { Categories }\end{array}$ & $\begin{array}{l}\text { Browse articles on similar topics from Cold Spring Harbor Protocols. } \\
\text { Apoptosis Assays ( } 73 \text { articles) } \\
\text { Cell Biology, general (1382 articles) } \\
\text { Characterization of Protein Complexes ( } 83 \text { articles) } \\
\text { Protein Expression and Interactions ( } 93 \text { articles) } \\
\text { Protein: Protein Interactions ( } 86 \text { articles) } \\
\text { Protein: Protein Interactions, general (112 articles) }\end{array}$ \\
\hline
\end{tabular}

